have developed under conditions of high humidity and heavy rainfall.

\section{British Poultry Science}

WHEN journals are being born at the rate of about two a day, the need for each new-comer must be scrutinized carefully. British Poultry Science, which has just been issued, is intended to be an international journal for the publication of original researches on the fowl, and for review articles (1, No. 1; April 1960. Pp. $72+x v i$. Initially two numbers annually, published in April and October. Annual subscription, 30s.; U.S.A. and Canada, 5 dollars. Single issues, 17s. net; U.S.A. and Canada, 2.75 dollars net. Edinburgh and London: Oliver and Boyd, Ltd., 1960). The contents of the first number give no indication of how it is to differ from, or improve on, the established journals which already cover this field, and, indeed, some of its contents have already been published in part elsewhere. Its further aim of bringing within its covers all kinds of seientific work on the fowl is also open to question, if only because research workers prefer to publish by discipline rather than by organism (and libraries also choose to purchase on this basis). The fowl is perhaps unique among animals in already having journals devoted to it; but it is not clear that they heve stimulated fundamental work on the biology of the fowl. It seems more likely that this stimulus will come from the rapidly increasing technical requirements of the poultry industry, which, in many aspects, have already outgrown their scientific bese. If this new journal is to prosper, its policy will have to be more clearly defined, particularly with respect to its emphasis on pure and applied science, and towards its anticipated lay readership.

\section{Local Health Service}

Six pilot studies into local health carried out under the direction of governments throughout the world are discussed in the first part of a report called "Local Health Service", by the World Health Organization (Report Series, No. 194. Pp. 49. Geneva: World Health Organization; London: H.M. Stationery Office, 1960. 2 Swiss francs ; $3 s .6 d$. ; 0.60 dollars). The Expert Committee on Public Health Administration in this, its third report, reaches the conclusion that the methods used are generally sound, and that, in the development of health services locally, such studies should become a routine procedure, not only as a means of assessing what services exist but also as a preliminary to the setting up of new services. The Committee discusses some of the factors affecting local health services: the need for decentralization of health services and for an efficient local administration; the various methods of organizing community effort in public health work; the importance of a closer alliance between genoral medical practice and local health service, and the consequent need for inculcating a proper approach to public health in the undergraduate medical curriculum; and the problems of urbanization arising from the great influx of people into the towns in response to industrial demand.

\section{Unesco Fellowships for Electronic Computing Research}

THE United Nations Educational, Scientific and Cultural Organization is offering six fellowships to be shared among member States to enable highly quali- fied specialists to undertake research in the use of electronic computers for the purpose of mechanical translation, the theory of switching or the use of computers for the reduction of geophysical data. The fellowships will normally be for six months and will carry a travel grant and a monthly allowance varying according to the country of study. Further information can be obtained from the United Kingdom National Commission for Unesco, Ministry of Education, Curzon Street, London, W.1.

\section{University News :}

Belfast

Among recent appointments to lectureships are the following: Dr. N.T. Dunwoody (engineering mathematics) and Mr. R. G. A. Stretch (psychology).

Birmingham

Dr. I. E. BusH has been appointed to the Bowman chair of physiology and to the directorship of the Department of Physiology from October 1. Dr. Bush has been a member of the external staff of the Medical Research Council since 1958, and is also a Sonior Research Fellow at New College, Oxford.

The title of professor of physiological chemistry has been conferred on Dr. W. V. Thorpe, who is at present reader in chemical physiology, as from October 1.

The following appointments are also announced. Lectureships : Dr. J. D. Dowell, Dr. P. Swinbank and C. P. van Zyl (physics); Dr. J. M. Webber (chemiriry); K. Foster (mechanical engineering); Dr. G. W. Rowe (industrial metallurgy); Dr. V. J. Emery (mathematical physics); Dr. E. F. StackForsyth (electrical engineering); R. N. Morris (econometrics and social statistics). Research Fellowships : Dr. T. F. Tuan (mathematical physics); Dr. N. Pessall and B. Cockayne (physical metallurgy); D. J. White to be Kenward Memorial Fellow (engineering production); H. R. Shaylor to be Staff Fellow in nuclear physics in the Department of Physics.

\section{Bristol}

Prof. T. K. EwER, at present professor of animal husbandry in the University of Queensland, has been appointed to the chair of animal husbandry. The following appointments are also announced. Lectureships: Dr. P. C. Caldwell (biochemistry within the Department of Zoology); A. J. B. Cruickshank (physical chemistry); Dr. I. O. Sutherland (organic ehemistry). Research Fellowship: Dr. P. H. Fowler (physics).

\section{Edinburgh}

THE following appointments have been announced: Readerships, Dr. J. P. Duguid (bacteriology) and Dr. C. A. Beevers (chemistry); Lectureships, J. R. Small (accounting and business methods), Dr. C. G. Thomson (clinical chemistry), Dr. D. J. MeAuliffe (ophthalmology), and Dr. F. M. Martin (public health and social medicine).

Leeds

Dr. F. HepburN has been appointed lecturer in medical physies.

Among the grants in aid of research which have recently been announced are: $£ 5,000$ to the Department of Physics from the Department of Scientific and Industrial Research; $£ 2,100$ to the 